\title{
Toxicity of Sediment-Associated Pesticides to Chironomus dilutus and Hyalella azteca
}

\author{
Yuping Ding $\cdot$ Donald P. Weston $\cdot$ Jing You $\cdot$ \\ Amanda K. Rothert • Michael J. Lydy
}

Received: 30 July 2010/Accepted: 18 October 2010/Published online: 5 November 2010

(C) The Author(s) 2010. This article is published with open access at Springerlink.com

\begin{abstract}
Two hundred sediment samples were collected and their toxicity evaluated to aquatic species in a previous study in the agriculturally dominated Central Valley of California, United States. Pyrethroid insecticides were the main contributors to the observed toxicity. However, mortality in approximately one third of the toxic samples could not be explained solely by the presence of pyrethroids in the matrices. Hundreds of pesticides are currently used in the Central Valley of California, but only a few dozen are analyzed in standard environmental monitoring. A significant amount of unexplained sediment toxicity may be due to pesticides that are in widespread use that but have not been routinely monitored in the environment, and even if some of them were, the concentrations harmful to aquatic organisms are unknown. In this study, toxicity thresholds for nine sediment-associated pesticides including abamectin, diazinon, dicofol, fenpropathrin, indoxacarb, methyl parathion, oxyfluorfen, propargite, and pyraclostrobin were established for two aquatic species, the midge Chironomus dilutus and the amphipod Hyalella azteca. For midges, the median lethal concentration $\left(\mathrm{LC}_{50}\right)$ of the pesticides ranged from 0.18 to $964 \mu \mathrm{g} / \mathrm{g}$ organic carbon (OC), with abamectin being the
\end{abstract}

Y. Ding · A. K. Rothert · M. J. Lydy

Department of Zoology, Fisheries and Illinois Aquaculture Center, Southern Illinois University, Carbondale, IL 62901, USA

e-mail: mlydy@siu.edu

D. P. Weston

Department of Integrative Biology, University of California, Berkeley, CA 94720-3140, USA

J. You $(\square)$

State Key Laboratory of Organic Geochemistry, Guangzhou Institute of Geochemistry, Chinese Academy of Sciences, Guangzhou 510640, China

e-mail: youjing@gig.ac.cn most toxic and propargite being the least toxic pesticide. A sublethal growth endpoint using average individual ash-free dry mass was also measured for the midges. The no-observable effect concentration values for growth ranged from 0.10 to $633 \mu \mathrm{g} / \mathrm{g}$ OC for the nine pesticides. For the amphipods, fenpropathrin was the most toxic, with an $\mathrm{LC}_{50}$ of 1-2 $\mu \mathrm{g} / \mathrm{g}$ OC. Abamectin, diazinon, and methyl parathion were all moderately toxic $\left(\mathrm{LC}_{50} \mathrm{~s} 2.8-26 \mu \mathrm{g} / \mathrm{g} \mathrm{OC}\right)$. Dicofol, indoxacarb, oxyfluorfen, propargite, and pyraclostrobin were all relatively nontoxic, with $\mathrm{LC}_{50}$ s greater than the highest concentrations tested. The toxicity information collected in the present study will be helpful in decreasing the frequency of unexplained sediment toxicity in agricultural waterways.

Pesticide residues in runoff from farmland can be a threat to benthic biota especially for creeks that receive return flow from irrigated fields (Schulz and Liess 1999). Toxicity to Chironomus dilutus larvae was seen in $13 \%$ of 39 sediment samples collected from a 10-county area in the agriculturally dominated Central Valley of California from 2002 to 2003 (Weston et al. 2004). Two hundred sediment samples were collected from 2002 to 2005 in the same area, and $27 \%$ of those sediments were toxic to the epibenthic amphipod Hyalella azteca (Weston et al. 2008). Comparison of measured pesticide concentrations in the toxic sediments with those concentrations known to cause mortality indicated that pyrethroid insecticides (mainly bifenthrin, esfenvalerate, lambda-cyhalothrin, and permethrin), and occasionally the organophosphate (OP) insecticide chlorpyrifos, were likely responsible for the toxicity in the majority of sediments. After accounting for 20 organochlorine (OC) pesticides, one OP pesticide, and seven pyrethroid pesticides (assuming toxicity is additive based on the assumption of a concentration addition model) 
in California agricultural sediments, the cause of toxicity remained unexplained in one third of the toxic samples (Weston et al. 2008).

Currently, hundreds of pesticides are used in California, but only a few dozen are analyzed in standard environmental monitoring. A significant amount of unexplained sediment toxicity may be due to pesticides that are in widespread use but have not been routinely monitored in the environment, and even if some of them were, the concentrations harmful to aquatic organisms are unknown. To decrease the frequency of unexplained toxicity in sediments affected by irrigated agriculture, chemical analysis and toxicity endpoints for more pesticides are needed. The present study focused on pesticides that possessed the following characteristics: relatively high use in the southern portion of California's Central Valley, ranked as high or very high for toxicity based on water exposure data reported in the United States Environmental Protection Agency (USEPA) Ecotox database, and soil absorption coefficients $\geq 1000$, suggesting that residues may be found in bed sediments. Based on a compilation of these data for agricultural pesticides in California (Lu and Davis 2009), 17 candidate pesticides were identified. This list was further decreased by eliminating those compounds that presented analytical difficulties, that had impending regulatory restrictions that were expected to substantially decrease use, that had expected low environmental persistence, or had been found to have very low $C$. dilutus or $H$. azteca toxicity in preliminary testing. The final list of compounds selected for the present study included two OPs (diazinon and methyl parathion), a pyrethroid insecticide (fenpropathrin), an OC acaricide (dicofol), an avermectin insecticide (abamectin), an oxidiazine insecticide (indoxacarb), a phenyl ether herbicide (oxyfluorfen), a sulfite ester acaricide (propargite), and a strobilurin fungicide (pyraclostrobin). The polarity of these pesticides varied, and the $\log$ values of their octanol-water partition coefficient (log $K_{\text {ow }}$ ) ranged from 3.3 to 6.0 (Table 1). Although most of the target pesticides have been applied for several decades, there are few or no data on sediment toxicity for common testing species, such as $C$. dilutus and H. azteca. Research on the toxicity of these compounds to aquatic algae, invertebrates, or fish has primarily focused on the water column (Burkepile et al. 2000; Tisler and Erzen 2006; Bringolf et al. 2007), although fewer studies have addressed sediment-associated toxicity. In the present study, sediment $\mathrm{LC}_{50}$ values of the nine pesticides were determined using $C$. dilutus and $H$. azteca according to USEPA standard protocols (USEPA 2000). Both lethal and sublethal effects (growth no-observable-effect concentrations [NOECs] using individual ash-free dry mass [AFDM]) of the nine target pesticides to $C$. dilutus was tested using one sediment, whereas three different sediments were used to determine the $\mathrm{LC}_{50}$ for $H$. azteca.

\section{Materials and Methods}

\section{Chemicals}

Propargite and the internal standard phenanthrene- $\mathrm{d}_{10}$ were purchased from AccuStandard (New Haven, CT), and all

Table 1 Pesticide type, chemical abstracts service numbers (CAS no.), annual use, and physicochemical parameters of the nine target pesticides

\begin{tabular}{|c|c|c|c|c|c|}
\hline Test pesticides & Type of pesticide & CAS no. & $\begin{array}{l}\text { Annual agricultural use } \\
\text { in California }(\mathrm{kg})^{\mathrm{a}}\end{array}$ & $\log K_{\mathrm{ow}}^{\mathrm{b}}$ & $\log K_{\mathrm{oc}}^{\mathrm{c}}$ \\
\hline Abamectin & Avermectin insecticide & $71751-41-2$ & 5,590 & 4.0 & 4.0 \\
\hline Diazinon & OP insecticide & $33-41-5$ & 116,000 & 3.8 & 2.3 \\
\hline Dicofol & OC acaricide & $115-32-2$ & 11,600 & 5.0 & $3.8-3.9$ \\
\hline Fenpropathrin & Pyrethroid insecticide & $39515-41-8$ & 14,800 & 6.0 & $5.6-5.7$ \\
\hline Indoxacarb & Oxadiazine insecticide & $173584-44-6$ & 24,200 & 4.5 & $3.3-3.9$ \\
\hline Methyl parathion & OP insecticide & 298-00-0 & 16,300 & 3.3 & 3.7 \\
\hline Oxyfluorfen & Phenyl ether herbicide & $42874-03-3$ & 275,000 & 4.5 & 6.2 \\
\hline Propargite & Sulfite ester acaricide & $2312-35-8$ & 174,000 & 3.7 & $3.6-3.9$ \\
\hline Pyraclostrobin & Strobilurin fungicide & $175013-18-0$ & 51,400 & 4.0 & $3.8-4.2$ \\
\hline
\end{tabular}

a 2008: http://www.cdpr.approximatelygov/docs/pur/purmain.htm

b Barceló et al. (1994), Hazardous Substances Data Bank 2008, Saito et al. (1993), (http://chemicalland21.com/lifescience/agro/FENPRO PATHRIN.htm), Environmental Monitoring Branch, Department of Pesticide Regulation (2003). DPR Pesticide, Fisher et al. (1993), U.S. Department of Agriculture, Agriculture Research Service, Pesticide Properties database (http://www.arsusda.gov/services/docs.htm?docid=14199), Xu (2001), European commission, health and consumer protection directorate-general (2001)

${ }^{\text {c } W i s l o c k i ~ e t ~ a l . ~(1989), ~ h t t p: / / e n t w e b . c l e m s o n . e d u / p e s t i c i d / d o c u m e n t / l e e o r g 1 / l e e o r g 3 . h t m, ~ T i l l m a n ~(1992), ~ X u ~ e t ~ a l . ~(2007), ~ B r u g g e r ~ a n d ~}$ Kannuck (1997), Appelo and Postma (1996), Pesticide Properties database (http://www.arsusda.gov/services/docs.htm?docid=14199), Xu (2001), European commission, health and consumer protection directorate-general (2001) 
other standards were from ChemService (West Chester, PA). The purities of the pesticides were $>95 \%$ as certified by the manufacturers. The surrogates $4,4^{\prime}$-dibromooctafluorobiphenyl (DBOFB) and decachlorobiphenyl (DCBP), Florisil solid-phase extraction (SPE) cartridges, and duallayer SPE cartridges packed with $300 \mathrm{mg}$ granular carbon black (GCB) and $600 \mathrm{mg}$ polymerically bonded ethylenediamine- $N$-propyl (PSA) were obtained from Supelco (Bellefonte, PA). Anhydrous sodium sulfate $\left(\mathrm{Na}_{2} \mathrm{SO}_{4}\right)$, copper powder, silica gel, and all pesticide grade solvents were purchased from Fisher Scientific (Pittsburgh, PA). Diatomaceous earth was obtained from Dionex Corporation (Sunnyvale, CA). Whatman no. 41 filter paper was from the Whatman Company (Maidstone, UK).

\section{Sediment Collection and Preparation}

Test sediments were collected from drinking water reservoirs and a lake in the vicinity of Berkeley, California. Sediment BRSP was a blend of sediments from Briones Reservoir and San Pablo Dam Reservoir. Sediment BR was from Briones Reservoir (different location in the reservoir than BRSP). Sediment LS was a blend of sediments from Lake Anza and San Pablo Dam Reservoir. The sediment was sieved through a 1-mm screen, homogenized, and then frozen until use. These sediments were selected to span a range of $\mathrm{OC}$ contents, and contained $0.5 \%$ (BR), $2.0 \%$ (BRSP), and $2.8 \%$ (LS) OC, respectively. Sediment toxicity data were all normalized to OC content. The test sediments were analyzed for the target pesticides before pesticide spiking and the toxicity tests, and no target pesticides exceeded the reporting limit of $1 \mathrm{ng} / \mathrm{g}$ dry weight (dw).

Sediments were spiked with each of the target pesticides using acetone as a carrier $(<700 \mu \mathrm{l}$ acetone $/ \mathrm{kg}$ wet sediment). A solvent control was prepared by adding the same quantity of acetone alone into the sediment. Sediments were thoroughly mixed for $0.5 \mathrm{~h}$ using a stainless steel paddle driven by an overhead motor. Then sediments were covered with aluminum foil and aged at $4^{\circ} \mathrm{C}$ in the dark for 12 days before use in the toxicity tests.

\section{Toxicity Tests}

Ten-day sediment toxicity tests with $C$. dilutus (third-instar larvae) and $H$. azteca (juveniles) were performed based on standard USEPA protocols (USEPA 2000). The midges were obtained from stock cultures maintained at the Fisheries and Illinois Aquaculture Center, Southern Illinois University at Carbondale, from cultures originally obtained from the USEPA Environmental Research Laboratory, Duluth, MN. Bioassays with $C$. dilutus were conducted with sediment spiked with each pesticide at four to six concentrations. Five replicates at each concentration were used for the experiments, and negative and solvent controls were included. After the 12-day aging period, $60 \mathrm{~g}$ wet sediment was distributed into each $350-\mathrm{ml}$ beaker (approximately $300 \mathrm{ml}$ overlying water), and the sediment settled overnight. Ten organisms were randomly placed into each beaker and held at $23^{\circ} \mathrm{C}$ with a $16: 8$-h light-todark photoperiod. Overlying water was renewed by addition of moderately hard water three times per day by an automatic water delivery system (total additions were approximately $180 \mathrm{ml} / \mathrm{d}$ ), with the excess water overflowing of the beaker through a screened hole. Organisms were fed $1.0 \mathrm{ml} 6 \mathrm{~g} / 1$ Tetrafin (TetraFin ${ }^{\circledR}$ (Tetra Holding, Blacksburg, VA, USA)) suspension daily. After the 10-day exposure, organisms were removed from the sediment by sieving through a $500-\mu \mathrm{m}$ sieve. Surviving midge larvae were counted and preserved in $10 \%$ formalin for later biomass measurements. A subsample of sediment at a midrange concentration for each pesticide was set aside at the beginning and end of each toxicity test and stored at $-20^{\circ} \mathrm{C}$ for chemical analysis. Mortality was calculated as total midge larvae added minus the surviving midges and, in addition to mortality, growth measured by AFDM was used as a sublethal endpoint for midge toxicity. The midge larvae surviving after the 10-day bioassays were placed in preashed aluminum pans at $60^{\circ} \mathrm{C}$ for $48 \mathrm{~h}$. The dried organisms were weighed to the nearest $0.001 \mathrm{mg}$ using a Mettler analytical balance (Schwiez, Switzerland) to obtain total mass and mean weights per surviving organism per replicate. Finally, the larvae and pans were ashed at $550^{\circ} \mathrm{C}$ for $3 \mathrm{~h}$ and reweighed to determine the AFDM.

Hyalella azteca toxicity tests generally followed the same procedures as the midge tests with the following exceptions. Organisms were obtained from cultures maintained at the University of California, Berkeley. Juveniles, 7-14 days old, were used for testing, with five to seven concentrations per pesticide and three replicates per concentration. Test organisms were fed daily with a yeast, cerophyll, and trout food mixture, and overlying water $(300 \mathrm{ml})$ was replaced by the addition of $500 \mathrm{ml}$ water/d (each renewal was $100 \mathrm{ml}$, and five renewals were used daily). After the 10-day testing period, survivors were recovered by sieving on a $425-\mu \mathrm{m}$ screen. Mortality was the sole endpoint evaluated for $H$. azteca.

In the $C$. dilutus tests, sediments were spiked with pesticides as high as necessary to obtain $\mathrm{LC}_{50}$ estimates. In the $H$. azteca tests, pesticides were not spiked $>20,000 \mathrm{ng} / \mathrm{g}$ nominal (except 153,000 ng/g in one case) on the assumption that higher concentrations would be environmentally unrealistic. If the $\mathrm{LC}_{50}$ was not reached at the highest concentration, the $\mathrm{LC}_{50}$ value was simply reported as "greater than" the maximum concentration used.

To verify good water quality, $\mathrm{pH}$, conductivity, ammonia, hardness, and alkalinity were measured at the 
beginning and end of each test, and temperature and dissolved oxygen were measured daily.

\section{Sediment Pesticide Analyses}

Sediment samples were analyzed for the target pesticides after the 12-day aging period (at the beginning of toxicity test) and the end of the 10-day toxicity test. Diazinon, dicofol, fenpropathrin, indoxacarb, methyl parathion, oxyfluorfen, and pyraclostrobin were analyzed according to the method of Wang et al. (2010). In brief, $10 \mathrm{~g}$ wet sediment was freeze dried (Labconco Corporation, Kansas City, MO) at $-50^{\circ} \mathrm{C}$ for $24 \mathrm{~h}$ and then extracted using an accelerated solvent extractor (ASE 200; Dionex, Sunnyvale, $\mathrm{CA}$ ) with $1: 1$ dichloromethane:acetone $(\mathrm{v} / \mathrm{v})$ at $100^{\circ} \mathrm{C}$ and 1500 pounds per square inch (psi) for two 5-min static cycles. The sample cleanup was performed using duallayer GCB/PSA SPE cartridges. After conditioning the cartridge with $3 \mathrm{ml}$ hexane, the extract was loaded onto the cartridge. Diazinon, dicofol, fenpropathrin, indoxacarb, methyl parathion, and oxyfluorfen were eluted with $7 \mathrm{ml}$ $30 \%$ dichloromethane in hexane, whereas pyraclostrobin was eluted off the GCB/PSA cartridge with $7 \mathrm{ml}$ toluene, concentrated to $1 \mathrm{ml}$, loaded onto a Florisil cartridge, and then eluted with $7 \mathrm{ml}$ hexane. All the eluents were concentrated to $1 \mathrm{ml}$ under nitrogen before instrumental analysis. Granular copper was added to the extracts to remove sulfur interference except for the OPs, and no copper was used for these extracts to avoid the potential loss of OPs by copper-induced hydrolysis and degradation (Tse et al. 2004; Wang et al. 2010; You et al. 2004).

Instrumental analyses for these seven pesticides were performed using an Agilent 6890 series gas chromatograph (GC) equipped with a micro-electron capture detector $(\mu \mathrm{ECD})$ and a nitrogen phosphorous detector (NPD) (Agilent, Palo Alto, CA). Dicofol, fenpropathrin, indoxacarb, oxyfluorfen, and pyraclostrobin were detected using $\mu \mathrm{ECD}$, and diazinon and methyl parathion were detected by NPD. The detector temperature for the ECD and NPD were set at $320^{\circ} \mathrm{C}$ and $290^{\circ} \mathrm{C}$, respectively. Two $\mu l$ of the sample were injected using an Agilent 7683 autosampler in pulsed splitless mode, and the quantification of analytes were confirmed using dual columns: an HP-5MS column (30 m $\times 0.25 \mathrm{~mm} \times 0.25 \mu \mathrm{m}$ film thickness; Agilent) and a DB-608 column $(30 \mathrm{~m} \times 0.32 \mathrm{~mm} \times 0.25 \mu \mathrm{m}$ film thickness; Agilent). The GC oven for the HP-5MS column was ramped from an initial temperature of $100-180^{\circ} \mathrm{C}$ at a rate of $10^{\circ} \mathrm{C} / \mathrm{min}$, then to $205^{\circ} \mathrm{C}$ at $3{ }^{\circ} \mathrm{C} / \mathrm{min}$ and held at $205^{\circ} \mathrm{C}$ for $4 \mathrm{~min}$ and then to $280^{\circ} \mathrm{C}$ at $20^{\circ} \mathrm{C} / \mathrm{min}$ and held at $280^{\circ} \mathrm{C}$ for $10.92 \mathrm{~min}$. The GC oven for the DB-608 column was ramped from 100 to $250^{\circ} \mathrm{C}$ at $10^{\circ} \mathrm{C} / \mathrm{min}$ and then to $280^{\circ} \mathrm{C}$ at $3^{\circ} \mathrm{C} / \mathrm{min}$ and held at $280^{\circ} \mathrm{C}$ for $20 \mathrm{~min}$. The flow rates of carrier gas were 3.8 and $1.8 \mathrm{ml} / \mathrm{min}$ for the
HP-5MS and DB-608 columns, respectively. Calibrations were based on peak area using five external standards. The standard solutions were made by dissolving $5,10,50,200$, and $250 \mathrm{ng}$ each pesticide and surrogate into $1 \mathrm{ml}$ hexane. The calibration curve was linear within the concentration range with linear regression coefficient $r^{2}>0.995$. To verify the performance of the analytical process, two surrogates (DBOFB and DCBP) were added to the freezedried sediment before ASE extraction. Validation of the sediment extraction method yielded extraction efficiencies of $76.5-126.6 \%$ in three different types of sediments for the target pesticides (Wang et al. 2010).

Propargite was extracted from sediment using a sonication-extraction method modified from USEPA method $3550 \mathrm{~B}$ and analyzed by $\mathrm{GC} / \mathrm{mass}$ spectrometry (GC/MS). Propargite samples were extracted with $60 \mathrm{ml}$ 50:50 (v/v) mixture of acetone-dichloromethane using three 15-min sonication periods and then filtered although a $0.45-\mu \mathrm{m}$ filter paper containing a small amount of anhydrous $\mathrm{Na}_{2} \mathrm{SO}_{4}$. Finally, the extract was concentrated using a Turbovap Evaporator (Hopkinton, MA) at $30^{\circ} \mathrm{C}$ to a final volume of $1 \mathrm{ml}$. Quantification of propargite was performed on an Agilent 6890 GC-5975 MS (Agilent) operated in the selected ion monitoring mode. A J\&W DB-5MS column $(30 \mathrm{~m} \times 0.25 \mathrm{~mm} \times 0.25 \mu \mathrm{m}$ film thickness; Agilent) was used. Helium was employed as the carrier gas at a flow rate of $1.5 \mathrm{ml} / \mathrm{min}$. The oven temperature program was $70^{\circ} \mathrm{C}$ held for $2 \mathrm{~min}$, increased at $25^{\circ} \mathrm{C} / \mathrm{min}$ to $150^{\circ} \mathrm{C}$, and at $3^{\circ} \mathrm{C} / \mathrm{min}$ to $200^{\circ} \mathrm{C}$, then at $8^{\circ} \mathrm{C} / \mathrm{min}$ to $280^{\circ} \mathrm{C}$ and held for $10 \mathrm{~min}$. The extract $(5 \mu \mathrm{l})$ was injected into the GC's silico-steel coated injection port using a pressurepulsed splitless injection at $75 \mathrm{psi}$ for $0.5 \mathrm{~min}$. The quantitation, target, and qualifier ions had masses of 135, 173, and 81 , respectively, and phenanthrene- $\mathrm{d}_{10}$ was used as the internal standard for calibration.

Finally, abamectin sediment concentrations were quantified using a high-performance liquid chromatograph (HPLC) with fluorescence detection after sonication extraction and derivatization. Approximately $10 \mathrm{~g}$ wet sediment was dried by mixing with $8 \mathrm{~g}$ anhydrous $\mathrm{MgSO}_{4}$ and $5 \mathrm{~g}$ anhydrous $\mathrm{Na}_{2} \mathrm{SO}_{4}$; a 50-ml aliquot of a 50:50 mixture of acetone and dichloromethane was added; and the sample was sonicated for $5 \mathrm{~min}$ in 3-s pulse mode using a highintensity ultrasonic processor (Tekmar, Cincinnati, OH). The extract was decanted and filtered through Whatman no. 41 filter paper. The procedure was repeated twice, and the extracts were combined and evaporated to approximately $5 \mathrm{ml}$ using a Turbovap. The extract was solvent-exchanged with hexane and the volume further reduced to $1 \mathrm{ml}$ under nitrogen. The extract was cleaned using a dual-layer GCB/ PSA SPE cartridge. After conditioning the cartridge with $3 \mathrm{ml}$ hexane, the extract was loaded, and abamectin was eluted off the cartridge with $10 \mathrm{ml}$ a mixture of acetone 
and hexane $(1: 1, v / v)$. The effluent was blown down to dryness under a gentle flow of nitrogen and derivatized by adding $300 \mu \mathrm{l}$ trifluoroacetic anhydride and acetonitrile $(1: 2, \mathrm{v} / \mathrm{v})$ and $200 \mu \mathrm{l}$-methylimidazole and acetonitrile $(1: 1, \mathrm{v} / \mathrm{v})$ (Diserens and Henzelin 1999). The derivatization product was analyzed by Agilent 1100 HPLC equipped with a fluorescence detector, and a Stablebond C18 analytical column was used for analyte separation. The fluorescence detector settings were an excitation wavelength of $365 \mathrm{~nm}$ and an emission wavelength of $475 \mathrm{~nm}$. The mobile phase (acetonitrile-water-methanol, 47.5:5:47.5, v/ $\mathrm{v} / \mathrm{v}$ ) was at a flow rate of $1.1 \mathrm{ml} / \mathrm{min}$. Calibrations were based on peak area using five external standards: 10,50 , 200, 250, and $500 \mathrm{ng}$ abamectin in acetonitrile, and all standards were derivatized before injection. The method showed good accuracy and precision with recoveries of abamectin of $88.1 \% \pm 6.6 \%(n=7)$ and $76.1 \% \pm 13.6 \%$ $(n=3)$ at spiked concentrations of 2 and $20 \mathrm{ng} / \mathrm{g} \mathrm{dw}$, respectively, and the method detection limit was $0.41 \mathrm{ng} / \mathrm{g}$ dw.

\section{Statistical Analyses}

$\mathrm{LC}_{50}$ values for the pesticides were estimated by using either probit or trimmed Spearman-Karber analyses, and Abbott's correction was applied in cases where the data were nonmonotonic (SAS version 8.02; SAS [Cary, NC] or CETIS, Tidepool Scientific [McKinleyville, CA]). Analysis of variance and Dunnett's tests (SAS version 8.02) were used to calculate NOECs by determining significant differences between control and treatment individual biomass $(p<0.05)$.

\section{Results}

Persistence of Target Pesticide Concentrations in Sediment During Bioassays

All analytical quality-control data including accuracy of surrogates (70-130\%), clean blank samples, accuracy of matrix spikes (75-125\%), and relative \% difference between matrix spikes $(<25 \%)$ fell within the satisfactory range. Fenpropathrin was persistent in all three types of sediment, with concentrations only decreasing 1-12\% during the 10-day exposure (Table 2). Pyraclostrobin concentrations were also relatively stable, with concentrations decreasing 5-35\% during the tests. Abamectin and propargite concentrations decreased only slightly in BRSP and LS sediments, but their concentrations decreased quickly in BR sediment, which had the lowest OC content. Dicofol was relatively persistent in LS sediment ( $28 \%$ loss), but its concentrations decreased quickly in BRSP and BR sediments (77-82\% loss and 65\% loss, respectively). Concentrations of indoxacarb and oxyfluorfen were decreased from 26 to $41 \%$ and from 3 to $51 \%$, respectively. Concentrations of the two OP insecticides, diazinon and methyl parathion, quickly decreased in all tested sediments, with \% losses from 50 to $77 \%$ and 74 to $100 \%$, respectively.

Regardless of the amounts of loss of pesticides from the sediments, the measured sediment concentrations were considered a better measure of actual exposure concentrations than the nominal values. Therefore, the reported toxicity and growth data were adjusted to actual concentrations using the mean values of the measured concentrations at the beginning and end of the 10-day toxicity tests.

Table 2 Percent loss of pesticides from the test sediments during the 10-day toxicity tests, based on measured concentrations at the beginning and end of the tests ${ }^{\mathrm{a}}$

\begin{tabular}{lllll}
\hline Test pesticides & $\begin{array}{l}\text { BRSP } \\
\text { (Chironomus } \text { tests) }\end{array}$ & $\begin{array}{l}\text { BRSP } \\
\text { (Hyalella tests) }\end{array}$ & $\begin{array}{l}\text { BR } \\
\text { (Hyalella tests) }\end{array}$ & $\begin{array}{l}\text { LS } \\
(\text { Hyalella } \text { tests })\end{array}$ \\
\hline Abamectin & 6 & $(22)$ & 77 & 24 \\
Diazinon & 64 & 77 & 50 & 57 \\
Dicofol & 77 & 82 & 65 & 28 \\
Fenpropathrin & 11 & 1 & 12 & 2 \\
Indoxacarb $^{\text {Methyl parathion }}{ }^{\mathrm{b}}$ & 38 & 41 & 26 & 26 \\
Oxyfluorfen $^{\mathrm{b}}$ & 99 & $86-97$ & $74-96$ & $93-100$ \\
Propargite $^{\text {Pyraclostrobin }}$ & 20 & $4-47$ & $3-51$ & $(22)-13$ \\
\hline
\end{tabular}

${ }^{a}$ Increases in concentrations are indicated within parentheses and are likely due to heterogeneity of the pesticides within the sediment or analytical errors rather than actual gains

b Some tests repeated twice; range of values is shown 
Lethality and Growth Impairment of Midges Exposed to Target Pesticides

Temperature, DO, pH, conductivity, ammonia, hardness, and alkalinity of overlying water were monitored throughout the bioassays, and all water parameters were within the acceptable range required by the USEPA (USEPA 2000). Survival of $C$. dilutus in both negative and solvent controls were $>88 \%$ in all tests, and average AFDM values ranged from 0.58 to $0.67 \mathrm{mg}$ for control organisms after the 10-day bioassays. There were no significant differences $(p>0.05)$ in the measurements between the negative and solvent controls. LC $_{50}$ values of the nine pesticides (Table 3), ranged from 0.18 to $964 \mu \mathrm{g} / \mathrm{g}$ OC. Abamectin was the most toxic of all tested compounds, with a 10-day $\mathrm{LC}_{50}$ of $0.18 \mu \mathrm{g} / \mathrm{g}$ OC, and propargite was the least toxic pesticide, with a 10-day $\mathrm{LC}_{50}$ of $964 \mu \mathrm{g} / \mathrm{g}$ OC. Pesticide toxicity to midges, from the most to least toxic, in BRSP sediment was in the order of abamectin, fenpropathrin, indoxacarb, diazinon, methyl parathion, pyraclostrobin, oxyfluorfen, dicofol, and propargite.

NOECs values for growth, based on average individual AFDM, are also listed in Table 3. The growth NOECs were approximately one half of the $\mathrm{LC}_{50}$ values in most cases, ranging from 19 to $69 \%$ of the $\mathrm{LC}_{50} \mathrm{~s}$.

\section{Mortality of Amphipods Exposed to Target Pesticides}

Three sediments with various OC contents were used for the $H$. azteca bioassay tests, with no appreciable difference found between negative and solvent control survival among sediments (mean survival was 95\%). All water-quality parameters were within acceptable ranges. Fenpropathrin was the most toxic of the nine pesticides tested, with an average 10-day $\mathrm{LC}_{50}$ of $1.6 \mu \mathrm{g} / \mathrm{g} \mathrm{OC}$ (Table 4). The two OP insecticides were less toxic, with $\mathrm{LC}_{50}$ values of diazinon ranging from 2.8 to $24.4 \mu \mathrm{g} / \mathrm{g} \mathrm{OC}$, and $\mathrm{LC}_{50}$ values of methyl parathion ranging from 2.8 to $12.7 \mu \mathrm{g} / \mathrm{g}$ OC. Abamectin was comparably toxic, with an $\mathrm{LC}_{50}$ averaging approximately $20 \mu \mathrm{g} / \mathrm{g}$ OC (range 11.3-26.2). $\mathrm{LC}_{50}$ concentrations for dicofol, indoxacarb, oxyfluorfen, and pyraclostrobin were not determined because $H$. azteca mortality did not reach $50 \%$ even at the highest spiked concentration $\left(\mathrm{LC}_{50} \mathrm{~s}>200 \mu \mathrm{g} / \mathrm{g}\right.$ OC). Propargite had a measurable $\mathrm{LC}_{50}$ value in BRSP sediment $(576 \mu \mathrm{g} / \mathrm{g}$ OC) but was also relatively nontoxic.

\section{Discussion}

\section{Persistence of Pesticide Concentrations During} Bioassays

Fenpropathrin was the only pyrethroid insecticide tested in the present study, and it was persistent in all sediments during the 10-day toxicity tests (Table 2). Similar persistence has been found for other pyrethroid insecticides in sediments in $C$. dilutus and $H$. azteca testing with the \% losses $<10 \%$ (Trimble et al. 2009) or $<25 \%$ (Maul et al. 2008). Bondarenko et al. (2006) also reported that sediment-associated pyrethroids were stable at $4{ }^{\circ} \mathrm{C}$ in the dark and that loss due to sorption to the container was negligible. Abamectin photodegrades in water to less bioactive compounds by oxidative and photo-oxidative mechanisms (Tisler and Erzen 2006); however, it is readily sorbed by sediment particles, and the present study showed that abamectin could be relatively stable in sediment, with the exception of BR sediment, which had extremely low OC

Table 3 Ten-day sediment $\mathrm{LC}_{50}$ values, $\mathrm{LC}_{50}$ values normalized to sediment $\mathrm{OC}$ content, and NOEC values normalized to sediment $\mathrm{OC}$ content for C. dilutus ${ }^{\mathrm{a}}$

\begin{tabular}{llll}
\hline Pesticide & $\mathrm{LC}_{50}\left(\mathrm{ng} / \mathrm{g}_{\mathrm{dw}}\right)(95 \% \mathrm{CI})$ & $\mathrm{LC}_{50}\left(\mu \mathrm{g} / \mathrm{g}_{\mathrm{oc}}\right)(95 \% \mathrm{CI})$ & $\mathrm{Growth} \mathrm{NOEC}\left(\mu \mathrm{g} / \mathrm{g}_{\mathrm{oc}}\right)$ \\
\hline Abamectin & $3.6(2.8-4.3)$ & $0.18(0.15-0.21)$ & 0.10 \\
Diazinon & $1085(954-1235)$ & $54.3(47.7-61.8)$ & 15.9 \\
Dicofol & $18308(14362-26383)$ & $915(718-1319)$ & 630 \\
Fenpropathrin & $177(107-353)$ & $8.9(5.4-17.7)$ & 1.7 \\
Indoxacarb & $226(191-255)$ & $11.3(9.6-12.8)$ & 3.2 \\
Methyl parathion & $6362(6099-6636)$ & $318(305-332)$ & 115 \\
Oxyfluorfen & $12603(8657-14323)$ & $630(433-716)$ & 312 \\
Propargite & $19279(17122-25252)$ & $964(856-\mathrm{y} 1263)$ & 633 \\
Pyraclostrobin & $6913(4958-8443)$ & $346(248-422)$ & 160
\end{tabular}

CI $95 \%$ confidence interval

${ }^{\text {a }}$ All data are from BRSP sediment $(2.0 \%$ OC) 


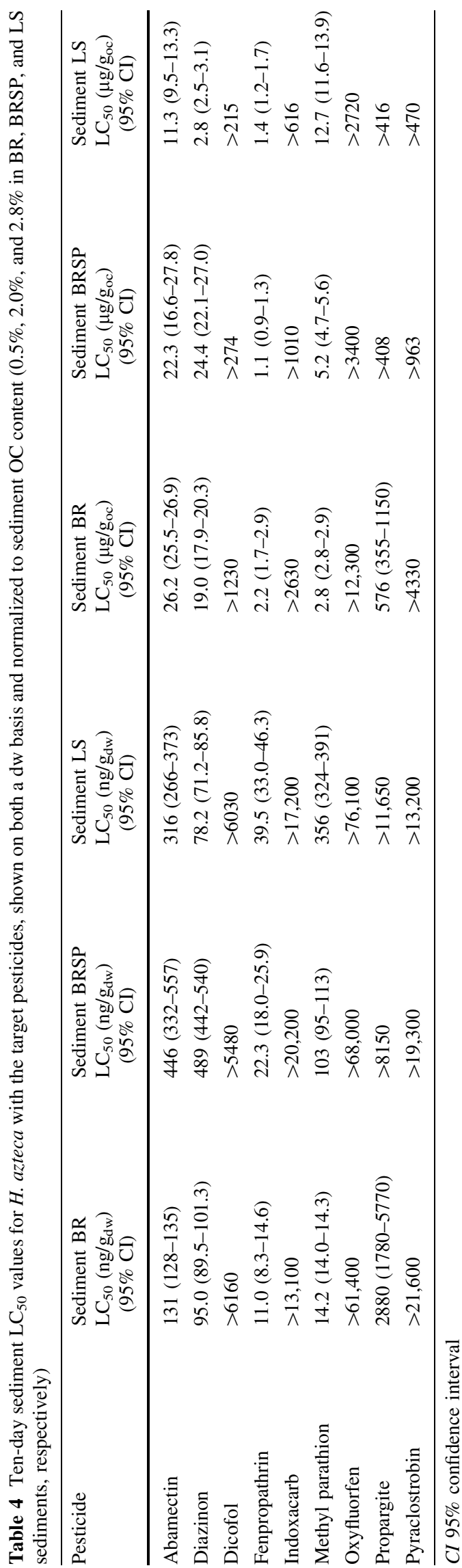

$(0.5 \%)$. Methyl parathion showed rapid loss of $74 \%$ to $100 \%$ in all three sediments used in the present study. This result is in agreement with previously published field data, where high concentrations of methyl parathion in Mediterranean sediments decreased to approximately $1 \%$ within 2 months (Badawy et al. 1984). The other OP, diazinon, also disappeared in the sediments fairly rapidly and slightly more quickly than the sediment half-life of 14-31 days reported previously (Bondarenko and Gan 2004). In addition to possible degradation in sediment, apparent loss of the compound may have been accelerated by dissolution into the overlying water that was regularly replaced throughout the toxicity tests.

Most persistence studies focus on soil or water column persistence, and few or no sediment-persistence data were available in the literature for the other pesticides, including dicofol, indoxacarb, oxyfluorfen, and pyraclostrobin. However, in development of the analytical methods for pesticides used in the present study, persistence of these compounds in sediment at $4^{\circ} \mathrm{C}$ during a 14-day aging period were evaluated (Wang et al. 2010). In that study, indoxacarb was relatively stable in all three sediments $(<20 \%$ loss); however, the stability of diazinon, oxyfluorfen, and pyraclostrobin was sediment-dependent. After 14 days, sediment concentrations of diazinon, oxyfluorfen, and pyraclostrobin decreased from 5 to $60 \%$, from 20 to $60 \%$, and from 5 to $40 \%$ in the three sediments, respectively.

The loss of the test pesticides during the 10-day testing period may be attributed to several reasons, including the following: (1) the loss of pesticides caused by degradation processes, such as photodegradation or biodegradation; (2) a decrease in extractability by sequestration to sediment particles (Peterson and Batley 1993); and, (3) low $\log K_{\text {ow }}$ values and relatively high water solubility of some compounds, which could lead to loss during overlying water exchanges. For example, methyl parathion has a $\log K_{\text {ow }}$ of 3.3 (Fisher et al. 1993) and a water solubility of $55-60 \mathrm{mg} / \mathrm{l}$ at $25^{\circ} \mathrm{C}$ (Verschueren 1996), and thus it could have been susceptible to loss from the water exchanges.

\section{Comparison With Previous Toxicity Studies}

To our knowledge, the present study is the first report of sediment toxicity thresholds for the nine target pesticides to midges or amphipods, with the exception of diazinon, fenpropathrin, and methyl parathion for which limited data were available. The threshold for diazinon toxicity in aqueous exposure is well established, but in a sediment matrix the only data available are reports of $H$. azteca mortality at $\geq 60 \mathrm{ng} / \mathrm{g}$ with a substrate composed of leaf litter (Moore et al. 2007a). Although that study did not 
provide a precise $\mathrm{LC}_{50}$ or data to permit $\mathrm{OC}$ normalization, the reported value is nearly within the range of our $\mathrm{LC}_{50}$ values on a dw basis, ranging from 78 to $489 \mathrm{ng} / \mathrm{g}$ depending on the sediment.

Fenpropathrin's $\mathrm{LC}_{50}$ value for $C$. dilutus, determined in the present study to be $9 \mu \mathrm{g} / \mathrm{g} \mathrm{OC}$, was approximately fourfold higher than other recently published values. $\mathrm{Xu}$ et al. (2007) reported fenpropathrin $\mathrm{LC}_{50}$ values of $2.36,2.5$, and $2.23 \mu \mathrm{g} / \mathrm{g}$ OC for sediments containing $1.44 \%, 1.88 \%$, and $5.03 \%$ OC, respectively. The difference in toxicity results between the present study and those of $\mathrm{Xu}$ et al. (2007) could have been due to the different instar larvae and/or the different sediment matrices used. Reported $C$. dilutus $\mathrm{LC}_{50}$ values for other pyrethroids included $24.5 \mu \mathrm{g} / \mathrm{g}$ OC for permethrin, $6.2 \mu \mathrm{g} / \mathrm{g}$ OC for bifenthrin, $2.8 \mu \mathrm{g} / \mathrm{g}$ OC for lambda-cyhalothrin (Maul et al. 2008), 13-67 $\mu \mathrm{g} / \mathrm{g}$ OC for cypermethrin (Maund et al. 2002), and 2.21-2.43 $\mu \mathrm{g} / \mathrm{g}$ OC for cyfluthrin (Xu et al. 2007). Compared with C. dilutus, $H$. azteca were more sensitive to pyrethroid insecticides, with sediment 10-day $\mathrm{LC}_{50}$ values of approximately $0.5-1 \mu \mathrm{g} / \mathrm{g}$ OC for many pyrethroids (bifenthrin, lambdacyhalothrin, deltamethrin, and cyfluthrin), and nearly $11 \mu \mathrm{g} / \mathrm{g}$ OC for permethrin (Amweg et al. 2005). The fenpropathrin $\mathrm{LC}_{50}$ value of 1.1-2.2 $\mu \mathrm{g} / \mathrm{g}$ OC observed in the present study indicates fenpropathrin toxicity to H. azteca that is comparable with that of many of the other pyrethroids.

Few sediment toxicity data were reported for the rest of the target compounds to the two test species. The 24-h $\mathrm{EC}_{50}$ of methyl parathion to the congeneric benthic midge $C$. riparius, determined with spiked sediment containing 3\% OC, was $0.13 \mu \mathrm{g} / \mathrm{g}$ OC (Fisher et al. 1993), and this value was much lower than the NOEC value found in the present study $(115 \mu \mathrm{g} / \mathrm{g}$ OC) using a 10-day test with C. dilutus. These results suggest that different species from the same genus may show very different sensitivity to the same contaminant.

No data were available in the literature for abamectin sediment toxicity thresholds for either midges or amphipods; however, some toxicity values have been published for soil-dwelling organisms. For example, Diao et al. (2007) evaluated the sublethal toxicity of abamectin to three groups of soil-dwelling invertebrates (springtails, earthworms, and enchytraeids). The $\mathrm{EC}_{10}$ values for reproduction were $50 \mathrm{ng} / \mathrm{g}$ for springtails, $60 \mathrm{ng} / \mathrm{g}$ for earthworms, and 12,800 ng/g for enchytraeids. Sun et al. (2005) tested the 14-day acute toxicity of abamectin for earthworms in an artificial soil and found an $\mathrm{LC}_{50}$ value of $17,100 \mathrm{ng} / \mathrm{g}$. The midge seems to be a much more sensitive species than these soil-dwelling invertebrates, with an $\mathrm{LC}_{50}$ value of $3.6 \mathrm{ng} / \mathrm{g} \mathrm{dw}$ or $0.18 \mu \mathrm{g} / \mathrm{g}$ OC, making abamectin the most acutely toxic of the pesticides tested in the present study.
Comparative Toxicity of Tested Pesticides Between Two Tested Species

Both $C$. dilutus and H. azteca were tested using BRSP sediment, so results from this matrix can be used to evaluate the relative sensitivity of the two species. $C$. dilutus was more sensitive to abamectin, indoxacarb, oxyfluorfen, and pyraclostrobin than $H$. azteca, whereas $H$. azteca was more sensitive to fenpropathrin, diazinon, and methyl parathion. The greater sensitivity of $H$. azteca to fenpropathrin is not surprising and is consistent with previous results of species sensitivity of other pyrethroids (Amweg et al. 2005; Maul et al. 2008). The relative sensitivity to dicofol and propargite were difficult to compare between the two species due to the lack of precise $\mathrm{LC}_{50}$ values for H. azteca.

The differences in species sensitivity among compounds illustrate the shortcomings of relying on a single species for toxicity testing in environmental monitoring. Of the seven pesticides for which our data allow comparison of sensitivity, $C$. dilutus is the more sensitive species to four pesticides, and H. azteca is more sensitive to three of them. Neither species is the obvious choice if sensitivity is the criterion for selection as a testing species. Although simultaneous testing with both species in environmental monitoring would take advantage of these differences in relative sensitivity, few programs do so, largely because of cost constraints. In California, where all of these pesticides are used, virtually all sediment testing is currently performed using H. azteca (Weston et al. 2004, Phillips et al. 2006, Holmes et al. 2008, Brown et al. 2010), but the data of the present study indicate that this is not the most protective choice with respect to all pesticides.

\section{Organism Toxicity Endpoints and Reported Environmental Field Concentrations}

To assess the potential ecological risk caused by these pesticides, it is necessary to compare toxicity endpoints with the reported sediment concentrations in the environment in which these compounds are applied. For at least fenpropathrin, methyl parathion, and diazinon, there are indications that environmental concentrations in sediment can exceed toxicity thresholds. Sediment from an agriculture-affected stream in northern California contained $8.5 \mu \mathrm{g} / \mathrm{g}$ OC fenpropathrin (Weston et al. 2009). In southern California, fenpropathrin was found in $68 \%$ of the dry season and $90 \%$ of the wet season sediment samples that were collected throughout a mixed land-use, and concentrations of fenpropathrin reached $19.4 \mathrm{ng} / \mathrm{g}(1.6 \mu \mathrm{g} / \mathrm{g}$ OC) at one site near a nursery outfall (Budd et al. 2007). Both of these sediment concentrations are higher than the H. azteca $\mathrm{LC}_{50}(1.1 \mu \mathrm{g} / \mathrm{g} \mathrm{OC})$ value, and within the range 
of the $C$. dilutus NOEC and $\mathrm{LC}_{50}(1.7$ and $8.9 \mu \mathrm{g} / \mathrm{g}$ OC) values determined in the present study, suggesting that fenpropathrin in field sediments may negatively impact populations of amphipods and chironomids and, furthermore, may influence the aquatic community and disrupt ecosystem balance.

Methyl parathion and diazinon were also widely detected in the environment. Methyl parathion concentration in sediment collected from Spittelwasser, Germany, was $1600 \mathrm{ng} / \mathrm{g} \mathrm{dw}$ (Brack et al. 1999). Methyl parathion concentrations in three Mississippi Delta oxbow lake sediments ranged from 24.9 to $36.5 \mathrm{ng} / \mathrm{g} \mathrm{dw}$ (Moore et al. 2007b). Both of these instances indicate potential toxicity to $H$. azteca $\left(\mathrm{LC}_{50}\right.$ values of $14.2-356 \mathrm{ng} / \mathrm{g} \mathrm{dw}$ ), although they are lower than the $C$. dilutus $\mathrm{LC}_{50}(6362 \mathrm{ng} / \mathrm{g} \mathrm{dw})$ value. Diazinon is only moderately hydrophobic (log $\left.K_{\mathrm{ow}}=3.8\right)$, and its water solubility $(40 \mathrm{mg} / \mathrm{l})$ suggests much of it may be in the water column, but high sediment concentrations have occasionally been reported. Diazinon accumulated in sediment at concentrations as high as $47,000 \mathrm{ng} / \mathrm{g} \mathrm{dw}$ in sediments of an urban creek in Alameda County, CA (Katznelson and Wetzig 1996). Irrigation ditches within a cranberry bog treated with diazinon reached 21,200 ng/g dw (Szeto et al. 1990). These reported diazinon concentration exceeded the $C$. dilutus NOEC $(318 \mathrm{ng} / \mathrm{g})$ or $\mathrm{LC}_{50}(1085 \mathrm{ng} / \mathrm{g})$ and H. azteca $\mathrm{LC}_{50}$ (78-489 $\mathrm{ng} / \mathrm{g} \mathrm{dw}$ ) values determined in the present study. These high diazinon concentrations may negatively impact amphipod and chironomid populations in the field.

Although many OCs have been banned or restricted for use since the 1970s, dicofol is currently in use. A dicofol concentration of $0.06 \mathrm{ng} / \mathrm{g} \mathrm{dw}$ was detected in sediment samples collected in a reservoir from Beijing, China (Xue et al. 2005), and the highest concentration of dicofol found in sediments of south Florida from 1991 to 1995 was $26 \mathrm{ng} / \mathrm{g} \mathrm{dw}$ (Miles and Pfeuffer 1997). In addition, a dicofol concentration of $24 \mathrm{ng} / \mathrm{g} \mathrm{dw}$ was reported in an agricultural stream in California (Pereira et al. 1996). However, these published environmental concentrations are all much lower than the $C$. dilutus NOEC $(12,600 \mathrm{ng} / \mathrm{g}$ $\mathrm{dw})$ and $\mathrm{LC}_{50}(18,308 \mathrm{ng} / \mathrm{g} \mathrm{dw})$ or $H$. azteca $\mathrm{LC}_{50}$ (>5480 ng/g dw) values.

Few or no bed sediment data were available for abamectin, indoxacarb, oxyfluorfen, propargite and pyraclostrobin, and these compounds are rarely among the analytes in environmental monitoring. The absence of data for abamectin was of particular concern given the high toxicity demonstrated to $C$. dilutus observed in the present study. Researchers in our group are collecting and analyzing sediments from the Central Valley of California where these target pesticides are in widespread use. Future field sediment data will be collected and compared with the lethal and sublethal thresholds of the two species established in the present study to assess the potential contribution of these pesticides to the observed toxicity effects and help to identify the cause of sediment toxicity, which can not be explained by the more typically monitored pesticides.

Acknowledgments California Proposition 40 and 50 funds, as administered by the California State Water Resources Control Board, Agricultural Water Quality Grant Program supported this study. We thank Rebecca Kelley for helping with chemical analysis. Jing You was supported by the "Hundred Talents" Program of the Chinese Academy of Sciences (kzcx2-yw-BR-05).

Open Access This article is distributed under the terms of the Creative Commons Attribution Noncommercial License which permits any noncommercial use, distribution, and reproduction in any medium, provided the original author(s) and source are credited.

\section{References}

Amweg EL, Weston DP, Ureda NM (2005) Use and toxicity of pyrethroid pesticides in the Central Valley, California, USA. Environ Toxicol Chem 24:966-972 [with correction in 24:1300-1301]

Appelo CAJ, Postma D (1996) Geochemistry, groundwater and pollution. A.A. Balkema, Brookfield, VT

Badawy MI, El-Dib MA, Aly OA (1984) Spill of methyl parathion in the Mediterranean Sea: a case study at Port-Said, Egypt. Bull Environ Contam Toxicol 32:469-477

Barceló D, Aboul-Kassim T, Bahnemann DW, Beek B, Bosland MC, Boule P, Dörr HG, Einax JW, Fabian P, Fiedler H, Gribble GW, Gruden D, Grune T, Hargrave BT, Hites RA (1994) The handbook of environmental chemistry. Available at: http://www. springerlink.com/content/110354/. Accessed 20 July 2010

Bondarenko S, Gan J (2004) Degradation and sorption of selected organophosphate and carbamate insecticides in urban stream sediments. Environ Toxicol Chem 23:11809-11814

Bondarenko S, Putt A, Kavanaugh S, Poletika N, Gan J (2006) Timedependence of phase distribution of pyrethroid insecticides in sediment. Environ Toxicol Chem 25:3148-3154

Brack W, Altenburger R, Ensenbach U, Möder M, Segner H, Schüürmann G (1999) Bioassay-directed identification of organic toxicants in river sediment in the industrial region of Bitterfeld (Germany) a contribution to hazard assessment. Arch Environ Contam Toxicol 37:164-174

Bringolf RB, Cope WG, Eads CB, Lazaro PR (2007) Acute and chronic toxicity of technical-grade pesticides to glochidia and juveniles of freshwater mussels (Unionidae). Environ Toxicol Chem 26:2086-2093

Brown JS, Sutula M, Stransky C, Rudolph J, Byron E (2010) Sediment contaminant chemistry and toxicity of freshwater urban wetlands in Southern California. J Am Wat Res Assoc 46:367-384

Brugger KE, Kannuck RM (1997) Tier 1 Environmental risk assessment of DPX-MP062 and competitive insecticides in the USA. Dupont Agricultural Products Document No. AMR 4635-97

Budd R, Bondarenko S, Haver D, Kabashima J, Gan J (2007) Occurrence and bioavailability of pyrethroids in a mixed land use watershed. J Environ Qual 36:1006-1012

Burkepile DE, Moore MT, Holland MM (2000) Susceptibility of five nontarget organisms to aqueous diazinon exposure. Bull Environ Contam Toxicol 64:114-121 
Diao X, Jensen J, Hansen AD (2007) Toxicity of the anthelmintic abamectin to four species of soil invertebrates. Environ Pollut 148:514-519

Diserens H, Henzelin M (1999) Determination of abamectin residues in fruits and vegetables by high-performance liquid chromatography. J Chromatogr A 833:13-18

Environmental Monitoring Branch, Department of Pesticide Regulation (2003) DPR Pesticide Chemistry database. Available at: http://www.cdpr.ca.gov/

European commission, health and consumer protection directorategeneral (2001) Review report for the active substance pyraclostrobin. Available at: http://ec.europa.eu/food/plant/protection/ evaluation/newactive/pyraclostrobin.pdf

Fisher SW, Lydy MJ, Barger J, Landrum PF (1993) Quantitative structure-activity relationships for predicting the toxicity of pesticides in aquatic systems with sediment. Environ Toxicol Chem 12:1307-1318

Holmes RW, Anderson BS, Phillips BM, Hunt JW, Crane DB, Mekebri A et al (2008) Statewide investigation of the role of pyrethroid pesticides in sediment toxicity in California's urban waterways. Environ Sci Technol 42:7003-7009

Katznelson R, Wetzig R (1996) Diazinon in sediments of urban creeks in Alameda County, CA. Abstracts, 6th Annual NorCal Society of Environmental Toxicology and Chemistry Meeting June 24-25, Sacramento, CA

Lu Z, Davis G (2009) Relative-risk evaluation for pesticides used in the Central Valley Pesticide Basin Blan Amendment project area. Available at: http://www.waterboards.ca.gov/centralvalley/ water_issues/tmdl/central_valley_projects/central_valley_pesticides/ risk_evaluation/index.shtml

Maul JD, Brennan AA, Harwood AD, Lydy MJ (2008) Effects of sediment-associated pyrethroids, fipronil, and metabolites on Chironomus tentans growth rates, mass, body condition, immobilization, and survival. Environ Toxicol Chem 27:2582-2590

Maund SJ, Hamer MJ, Lane MC, Farrelly E, Rapley JG, Goggin UM, Gentle WE (2002) Partitioning, bioavailability, and toxicity of the pyrethroid insecticide cypermethrin in sediments. Environ Toxicol Chem 21:9-15

Miles CJ, Pfeuffer RJ (1997) Pesticides in canals of South Florida. Arch Environ Contam Toxicol 32:337-345

Moore MT, Lizotte RE Jr, Smith S Jr (2007a) Toxicity evaluation of diazinon contaminated leaf litter. Bull Environ Contam Toxicol 78:168-171

Moore MT, Lizotte RE Jr, Knight SS, Smith S Jr, Cooper CM (2007b) Assessment of pesticide contamination in three Mississippi Delta oxbow lakes using Hyalella azteca. Chemosphere 67:2184-2191

Pereira WE, Domagalski JL, Hostettler FD, Brown LR, Rapp JB (1996) Occurrence and accumulation of pesticides and organic contaminants in river sediment, water and clam tissues from the San Joaquin River and tributaries, California. Environ Toxicol Chem 15:172-180

Peterson SM, Batley GE (1993) The fate of endosulfan in aquatic ecosystems. Environ Pollut 82:143-152

Phillips BM, Anderson BS, Hunt JW, Huntley SA, Tjeerdema RS, Kapellas N et al (2006) Solid-phase sediment toxicity identification evaluation in an agricultural stream. Environ Toxicol Chem 25:1671-1676

Saito H, Koyasu J, Yoshida K, Shigeoka T, Koike S (1993) Cytotoxicity of 109 chemicals to goldfish GFS cells and relationships with 1-octanol/water partition coefficients. Chemosphere 26:1015-1028

Schulz R, Liess M (1999) A field study of the effects of agriculturally derived insecticide input on stream macroinvertebrate dynamics. Aquat Toxicol 46:155-176
Sun Y, Diao X, Zhang Q, Sheng J (2005) Bioaccumulation and elimination of avermectin B1a in the earthworm (Eisenia fetida). Chemosphere 60:699-704

Szeto SY, Wan MT, Price P, Roland J (1990) Distribution and persistence of diazinon in a cranberry bog. J Agric Food Chem $38: 281-285$

Tillman A (1992) Residues, environmental fate and metabolism evaluation of dicofol prepared for the FAO expert group on pesticide residues [Report No. AMT 92-76]. Rohm and Haas, Philadelphia, PA

Tisler T, Erzen NK (2006) Abamectin in the aquatic environment. Ecotoxicology 15:495-502

Trimble AJ, Weston DP, Belden JB, Lydy MJ (2009) Identification and evaluation of pyrethroid insecticide mixtures in urban sediments. Environ Toxicol Chem 28:1687-1695

Tse H, Comba M, Alaee M (2004) Method for the measurement of organophosphate insecticides in water, sediment and biota. Chemosphere 54:41-47

United States Environmental Protection Agency (2000) Methods for measuring the toxicity and bioaccumulation of sediment-associated contaminants with freshwater invertebrates, 2nd ed, EPA 600/R-99/064. Office of Research and Development, Duluth MN

Verschueren K (1996) Handbook of environmental data on organic chemicals. Van Nostrand Reinhold, New York, NY

Wang DL, Weston DP, Ding YP, Lydy MJ (2010) Development of a sample preparation method for the analysis of current-use pesticides in sediment using gas chromatography. Arch Environ Contam Toxicol 58:255-267

Weston DP, You J, Lydy MJ (2004) Distribution and toxicity of sediment-associated pesticides in agriculture-dominated water bodies of California's Central Valley. Environ Sci Technol 38:2752-2759

Weston DP, You J, Amweg E, Lydy MJ (2008) Sediment toxicity in agricultural areas of California and the role of hydrophobic pesticides. In: Gan J, Spurlock F, Hendley P, Weston D (eds) Synthetic pyrethroids: occurrence and behavior in aquatic environments. American Chemical Society, Washington, DC, pp 26-54

Weston DP, You J, Harwood AD, Lydy MJ (2009) Whole sediment toxicity identification evaluation tools for pyrethroid insecticides: III. Temperature manipulation. Environ Toxicol Chem 28:173-180

Wislocki PG, Grosso LS, Dybas RA (1989) Environmental aspects of abamectin use in crop protection. In: Campbell WC (ed) Ivermectin and abamectin. Springer Verlag, New York, pp 182-200

$\mathrm{Xu} \mathrm{S}$ (2001) Environmental fate of propargite. Environmental Monitoring and Pest Management Department of Pesticide Regulation. Available at: www.cdpr.ca.gov/docs/emon/pubs/ fatememo/proprgte.pdf

Xu Y, Spurlock F, Wang Z, Gan J (2007) Comparison of five methods for measuring sediment toxicity of hydrophobic contaminants. Environ Sci Technol 41:8394-8399

Xue N, Xu X, Jin Z (2005) Screening 31 endocrine-disrupting pesticides in water and surface sediment samples from Beijing Guanting reservoir. Chemosphere 61:1594-1606

You J, Weston DP, Lydy MJ (2004) A sonication extraction method for the analysis of pyrethroid, organophosphate, and organochlorine pesticides from sediment by gas chromatography with electron-capture detection. Arch Environ Contam Toxicol 47:141-147 